\title{
Military Technical Developments in the Frame of the Czech Armed Forces development
}

\author{
Zbyšek KORECKI ${ }^{1}$, Miroslav JANOŠEK², Blanka ADÁMKOVÁ ${ }^{3}$ \\ ${ }^{1}$ University of Defence in Brno University, Department of Air Forces, Kounicova 156/65, 66210 Brno, Czech Republic \\ ${ }^{2}$ University of Defence in Brno University, Department of Air Forces, Kounicova 156/65, 66210 Brno, Czech Republic \\ ${ }^{3}$ Ministry of Defence, Tychonova 221/1, 16000 Praha 6, Czech Republic
}

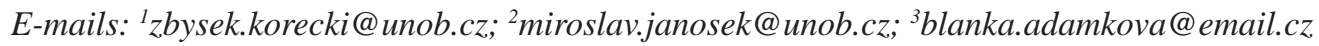

\begin{abstract}
In the horizon of 2030, the Ministry of Defense of the Czech Republic set out significant changes, supported not only by an anticipated budget increase, but also by an efficient process of public procurement, and an increase in the number of members of the armed forces to respond to current and future threats.

In 2019, the Czech Air Force capabilities the development was ensured by the acquisition of twelve helicopters, eight MADR mobile 3D radars, and two new CASA aircraft.

An important year for the Air Force development is the year 2027, when the lease agreement for the supersonic aircraft JAS 39, will be terminated.
\end{abstract}

KEY WORDS: modernization, acquisition process, life cycle engineering, life cycle cost, supersonic, support processes

\section{Introduction}

The armed forces modernization associated with all the threats discussed at the London Summit, but the authors highlight the following text on hybrid threats and the 5G networks construction, the Baltic Air Protection, military mobility in Europe and technology and cyber defense [1].

The modern weapon systems acquisition, in particular aeronautical and support technology, requires the aircraft life cycle phase's analysis to define required system lifetime funding. The acquisition process defines four phases of the material life cycle: the design and development phase, the production phase, the operation phase, and the recycling and disposal phase $[2,3,4]$.

The current approach to plane life-cycle assessment does not stress the decommissioning phase of the aircraft, although a significant part of the fleet will be in the end of life phase in the next period. The following text describes the life cycle engineering (LCE) phases and the determination system boundaries [5, 6]. The Czech Armed Forces acquires new aviation material that is already in use or used by other armed forces of the Alliance.

The design part ends with testing, and it is necessary to certify all areas ensuring the product working use before starting mass production. The production phase consists of the following steps: resource extraction, production, material logistic, final assembly, and completion.

Air traffic is a challenging phase that requires direct and indirect activities. Direct operations include activities and resources involved in aircraft operations and include flight operations, maintenance, and overhaul [7, 8]. Indirect operations include ticketing and administration. An air traffic important part is also the airport infrastructure development, which must create conditions for flight operation in all dimensions according to the type of operated aircraft $[9,10]$.

Reuse of resources is a fundamental principle of the last phase of life, mainly due to environmental requirements. Life cycle engineering (LCE) combines the cost of all phases of the material life cycle, taking into account environmental protection requirements by implementing technological constraints [11, 12]. The cost of all stages of the life cycle must be part of the preliminary design. LCE processing is dependent on the data obtained from all aircraft subsystems. The collection and analysis of working data determined by the willingness of all participating parties to share information [13]. Providers of maintenance and other aircraft support services faced requirements to cut preventive repair time.

eMaintenance implementation is important phase of new approaches in aircraft maintenance and include

\footnotetext{
${ }^{1}$ Corresponding author.

E-mail address: zbysek.korecki@unob.cz.
} 
monitoring, collecting, recording, and distributing real-time aircraft technical data [14, 15]. The information and communication technologies development of enables the integration of embedded tests, external tests at various maintenance levels, technical information, diagnostics, forecasting, and other supporting information sources during maintenance and support processes.

The authors analysed fundamental the Czech Armed Forces modernization steps into 2030. The process includes not only the new weapon systems acquisition but also the proper education and training of people for the national and coalition cooperation needs.

\section{Data Collection Process}

The research carried out in two experiments. The first step is to select publications. The criterion for choice for the first experiment is the phrase "technological development" of publications indexed on WoS. The selection resulted in 684 publications. Authors filtered and used from these publications only publications with 40 or more citations.

The selection criteria for the second experiment were the emaintenance and military capability keywords in all fields of publication data. The selection resulted in 31 publications. Authors used only publications with more than 50 citations from these publications.

\subsection{Approaches to the Concept of Security}

Despite the fact that we find different approaches to the concept of security, it is necessary to find a common interpretation of the term and transform it into real steps of the armed forces of the Czech Republic in the process of implementing the modernization of the defense system.

A generally accepted approach to security in assessing the security dimensions of the state can be defined in military, political, economic, environmental, and social aspects. This method of assessing the nature of the security dimensions then illustrates the nature of the security of the community under investigation.

Nation states define the necessary capability of keeping up territorial integrity and security on Alliance predictable threats basis. The armed forces modernization may be associated with all the threats discussed at the London Summit, but the authors highlight the following text on hybrid threats and the 5G networks construction, the Baltic Air Protection, military mobility in Europe and technology and cyber defense. The modern weapon system acquisition, in particular aerospace, and support technology, requires the analysis of aircraft life cycle phases to define the required funding for the lifetime of the system. The acquisition process defines four phases of the material life cycle: the design and development phase, the production phase, the operation phase, and the recycling and disposal phase [16].

The current approach to aircraft life-cycle assessment does not accentuate the decommissioning phase of the aircraft, although a significant part of the fleet will be in the end of life phase in the next period. The world's largest aircraft manufacturers predict that during comming years a significant number of operated aircraft reach the end of their life cycle will be decommissioned and replaced with new types. In the following, the life cycle engineering (LCE) phases are defined, and the boundaries of the system are determined. The Army of the Czech Republic acquires new aviation material that is already in use or is being used by other armed forces of the Alliance.

Nevertheless, it is necessary to mention that the development phase has its periods [17]: design and engineering, construction of test facilities and test aircraft, and testing itself. Subsequent series production can be started provided that all ground and flight tests needed for certification have been performed.

The production phase consists of the following steps: sourcing, production, material logistics, final assembly, and finishing. Disassembly can be summarized into several commodities: aluminum, epoxy resin, glass, steel, nickel, magnesium, copper, and titanium [18]. Air traffic is a demanding phase of the system that requires the direct and indirect activities implementation.

Direct operations include activities and resources needed to make sure the aircraft operation and include flight operations, maintenance, and overhaul [19]. Indirect operations include ticketing and administration. An important part of air traffic is also the airport infrastructure, which must create the conditions for flight operations and flight operation areas dimensions according to the type of aircraft operated [20].

The last phase of the life cycle is recycling and disposal, where we find four options for material operations [21] - reuse, recycling, energy recovery, and land filling. Reuse is a fundamental principle of the last phase of life, mainly due to environmental requirements. Recycling can be further subdivided into the use of material in a clean state, or implemented in chemically and physically combined parts [22]. Life cycle engineering (LCE) combines the cost of all phases of the material life cycle, taking into account environmental protection requirements by implementing technological constraints. The cost of all stages of the life cycle must be part of the preliminary design.

Given the number of parties involved and the complexity of aircraft systems, LCE processing is dependent on data not available to the extent required [23]. A compromise is therefore reached in setting the LCE so that all 
expenditure is included with sufficiently high precision, but it does not guarantee the inclusion of all expenditure. Providers of maintenance and other support for aircraft maintenance and support are faced with requirements to cut preventative repair time, or by introducing eMaintenance, which is considered an important phase of aircraft maintenance. eMaintenance includes monitoring, collecting, recording and distributing real-time aircraft technical data, generated maintenance data, and further decision-making and performance support with the ability to share to all stakeholders 24/7 regardless of geographical location. Implementing eMaintenance will improve reliability, safety, and cut the life cycle cost of critical aircraft systems in the maintenance process. The information and communication technologies development enable the embedded tests integration, external tests at various maintenance levels, technical information, diagnostics, forecasting and other sources of supporting information during maintenance and support processes.

The authors analyzed the fundamental modernization steps of the Czech Armed Forces in 2030, when it is not only the new weapon systems acquisition, but also the proper education, and training of personnel for the needs of national, and coalition cooperation.

\subsection{Security Situation in Czech Republic}

The Czech Republic Defense Strategy of 2017, which is still in force today, defines in detail the risks to the EU countries security [24]. It emphasizes the analysis of the possibility and danger of local and regional conflicts due to ethnic or geographical disputes. It also draws attention to the risk of uncontrolled nuclear weapons proliferation and carriers, the threat of terrorism, cyber and energy security, and, last but not least, the effects of environmental change and organized crime.

Changing security levels, demographic trends, and growing social differences in source countries create demands to respond to new or old-age security challenges related to migration and extremism. The information society highlights security threats in cyber-security, especially in the area of critical infrastructure related to cyber-crime or failure of control systems due to cyber-attack.

We are witnessing an attack on the information system of the Benešov Hospital through a ransomware attack [25]. Possible scenarios of threats and security challenges, apart from the military attack, are associated with the already defined danger in new forms. The security challenge is hybrid warfare, which can be defined as: "a comprehensive strategic (systemic) model driven by states to achieve geopolitical goals by non-military methods.

The system is changing as technology evolves and at the EU level in the field of knowledge and military science. The traditional goals of military operations were: destroy - occupy - smash, which were later redefined in the asymmetrical fight to exhaust - break - bleed. The current strategy of cyber-warfare is break-cause brokenoccupy hybrid warfare.

\section{Major Projects and Challenges of Developing Benefits to Achieve Milestone 2025}

The Czech Armed Forces development aim is to defend Czech Republic interests and the continuous capabilities development to fulfill its obligations for the common defense. According the implementation of the acquisition plan, 22nd Helicopter Base at Namest nad Oslavou, will be rearm. At the same time, there will be the airborne regiment creation and battalion support deployable forces. The cybernetic forces achieved the ability to run in the information environment when the cyber domain is reached.

The air forces will make sure the defense of Czech airspace within NATINAMDS using supersonic JAS39 Gripen aircraft. The Czech Government and the Ministry of Defense will decide, soon, on the tactical aviation future form.

The subsonic air force will complement the capabilities of the supersonic air force by providing NaPoSy air defense and providing direct air support for Ground Forces. Czech Armed Forces modernization will integrated short and medium range anti-aircraft missiles and implement precise satellite-guided ammunition to counteract ground targets under any weather conditions.

A new helicopter platform with the ability to fire with precisely guided ammunition against armored targets will be introduced. The Mi-171Š helicopters will be upgraded. Ensuring strategic air transport and in-flight refueling capability will be addressed by joining international projects. Operated CASA C-295 aircraft will be upgraded, and two CASA C-295MW aircraft will be purchased. MADR-type radars will be put into operational use, and in accordance with the Czech Republic's commitments will be prepared for detachment, in favor of Alliance forces. Technical support for the operation of the backbone radar Fixed Air Defense Radar (FADR) Sokolnice will be provided.

The process of integrating the unified IFF Mode 5 identification system and the implementation of allied tactical datalinks into the main vzS systems will continue.The Common European Sky project will complete the complete renewal of the instrument approach system at all military air bases.The JTAC / TACP unit will be supplemented with the technology and material required to secure the Taskf Force (TF) and meet the Alliance's obligations. 
Maintaining the air defense capability of the Czech Republic and TF Ground Forces will be solved by the short-range anti-aircraft missile system acquisition with the medium-range missiles possibility using and portable anti-aircraft missile the acquisition ensemble of the very short-range category.

Increased levels of military security are already reflected in acquisition processes, especially for the needs of the Air Force. At present, the Czech Air Force has 36 combat aircraft (JAS-39, L-159) and 17 combat helicopters (Mi-24, Mi-35).

Other aviation equipment includes 5 L-39 training aircraft, 16 L-410, Jak-40, CL-601 Challenger, A-319 $\mathrm{CJ}$, and CASA C-295M training and observation aircraft, and 34 unarmed transport, and multipurpose helicopters types Mi-8, Mi-17, Mi-171S, and W-3A Sokol.

\subsection{Acquisition of CASA Aircraft}

The ACR now operates four CASA C-295M aircraft, which have flown almost 15,000 flight hours since their introduction into service in 2010, carrying more than 65,000 passengers, while maintaining a high level of reliability and flight safety. CASA C-295M aircraft perform tasks in training, ensure the rotation of soldiers, and transport of material to foreign missions and transport of soldiers and equipment for foreign exercises and show a high degree of reliability.

One aircraft has been operating since 2013 in favor of the international observation mission MFO on the Sinai Peninsula, with the assumption of deployment at least by the end of 2020. CASA aircraft are, used to make sure the MEDEVAC program, which is prepared for air transport of the wounded and sick personal and for humanitarian missions according to the Czech Republic Government decision.

The purchase of two more CASA aircraft was originally planned between 2023 and 2024. The new CASA C-295MW plane will expand the existing fleet's carrying capacity and take on the tasks being carried out by two morally and technically obsolete Jak 40s with much higher operating costs and lower carrying capacity. The Jak 40 aircraft are already at the end of their technical life and will be decommissioned in 2020 .

The basis for negotiations on a possible acceleration of the supply of CASA aircraft compared to the original acquisition assumption was the manufacturer's offer in December 2018 to supply aircraft from current production. Representatives of the MoD signed a contract [26] with Airbus Defense and Space, SA, for the delivery of two new tactical transport aircraft CASA C-295MW. Airplanes were delivered for the period 2020 and 2021.

Acquisition of two newest C-295MW's with full working equipment, spare parts, ground handling equipment, and manufacturer's warranties as required by the Czech Armed Force (CAF) costs CZK 1,94 billion. The repayment schedule was set for the period 2019 to 2023. At the same time, the costs of training aviation personnel for the latest navigation, communication, and other special aircraft systems will be significantly lower.

Simultaneously with the new aircraft was signed the contract for the existing planes modernization. The existing four CASA C-295M aircraft will be upgraded by the manufacturer to the latest standard. The goal of upgrading CASAs is to meet ICAO requirements so that all CAF aircraft meet the latest international air traffic requirements and trends. The modernization program is spread over the period 2019 to 2021, when all aircraft includes modernization of communication, navigation, and avionics systems, flight planning system, installation of satellite communication, and DATA link interface, or supply of new spare parts for upgraded systems and components and new ground equipment. The total modernization program value of the four CASA C-295M aircraft is CZK 360,3 million (CZK 436,0 million including VAT).

The current acquisition will contribute to an increase in the total air transport capacity of the Air Force. New acquisitions of the Army of the Czech Republic aim to cut the number of aircraft types operated, which will result in lower logistic flying costs.

\subsection{Acquisition of Mobile Radar}

In December 2019, an intergovernmental Czech-Israeli agreement on the acquisition of eight 3D mobile radars (MADR) was signed in Prague by signing a contract between the Ministry of Defense's representative and the Director of the Israeli Ministry of Defense Agency of the Directorate of International Defense Cooperation (SIBAT).

The value of the order is CZK 3,5 billion with VAT. The acquisition was preceded by the processing of independent evaluators' reports. Currently, the CAF Air Force is using Russian-made radars that have already exceeded the life cycle. The delivery of new Israeli radars will ensure compatibility with NATO systems. The radars will be continuously tested before being put into operation in 2023.

In accordance with the Government's request, the Ministry of Defense demanded the Czech industry involvement from MADR radar suppliers. The level of involvement of Czech companies in the performance of public contracts should reach a minimum level of $30 \%$. The main partners of the Czech industry are Elta and Retia, a.s., and 
VTÚ, s.p. The terms of the contract will also enable the acquisition of know-how and production capacity so that MADR radars can be operated and serviced independently by the Czech Republic through Retia.

\subsection{Modernization of Helicopter Air Force}

The Czech Air Force modernization also continues in the field of generation replacement of helicopter aviation systems. The Czech Ministry of Defense has acquired eight new UH-1Y Venom helicopters and four AH$1 \mathrm{Z}$ Viper helicopters with an estimated useful life of 25 years.

Helicopters will be equipped with aircraft machine guns, guided missiles against tanks, laser-guided missiles air-ground, 20mm air cannon, modern observation and communication systems, and elements of active and passive protection. The H-1 system also provides air transport and rescue services.

Modernization of the helicopter air force is given by the need to replace $10 \mathrm{Mi}-24$ machines, which will be excluded from the structure of the Czech Air Force in 2025. The helicopter modernization is given the need to replace $10 \mathrm{Mi}-24$ machines, which will be removed from the structure of the Air Force in 2025.

The supply of 12 newly acquired machines will be realized by 2023 . The contract also includes the delivery of the necessary equipment, ammunition, training, security, and training. The helicopters will be procured through an intergovernmental agreement and will ensure fast, smooth, and reliable delivery of spare parts. The need to train the necessary number of pilots and aviation technicians remains a problem. It is assumed 36 pilots on both machine variants. The possibility is given by $85 \%$ conformity of flying requirements. The Air Force will use other Mi helicopters by 2035 .

The main tasks performed are the transport of persons and material or for cooperation with rescue workers. The agreement on the acquisition of helicopters will also include an agreement on industrial cooperation. The manufacturer will hand over to the CAF with all necessary documentation to enable Czech companies to service and keep up and subsequently participate in modernization.

\subsection{Modernization of Air Defense RBS-70NG}

Technically advanced modern air defense systems are becoming increasingly important in the state defense.

Air defense system units perform tasks in protecting military task forces in operations on the territory of the state or abroad, and in ensuring the air defense of important civilian and military centers and critical state infrastructure. They allow effective defense not only against aircraft or helicopters, but also against all other means of air attack, including unmanned aerial vehicles, precision-guided ammunition, ballistic, hypersonic, and flatrange missiles.

The analyzed analytical study analyzed the threats and ambitions of individual Member States in the modernization of air defense in the medium and long term intention of the V4 states in the replacement of existing air defense weapon systems. An important part was also ensuring long-term logistic support throughout the entire life cycle. Experiences from the national acquisition project implementation were used, including strategic MoD projects for the acquisition of the Portable Anti-Aircraft Missile System RBS-70NG and Anti-Aircraft System SHORAD. The reason for the anti-aircraft set acquisition is the priority objective fulfillment of maintaining and, in particular, deploying deployable air defense capabilities of very short to medium range to strengthen the air defense of the state and combat support of the military in the country and abroad.

25th anti-aircraft missile regiment now has 16 Swedish RBS-70, the earlier generation sets, and about 100 laser-guided missiles Mk.I, and Mk.II, with a long-range $5000-6000 \mathrm{~m}$ and height $3000 \mathrm{~m}$. And the latest RBS 70 NG missiles with a range of 220 to $9000 \mathrm{~m}$ and $5000 \mathrm{~m}$ height. Buying 16 more modern sets of the new generation RBS-70NG and hundreds of other missiles anti-aircraft system will much strengthen the combat capabilities of the Army of the Czech Republic [27]. They will be used not only for the Czech Republic airspace protection but also for the fulfillment of the ground air defense tasks within the framework of NATO international task forces.

With the previous generation, the new sets share the same system of training and training of soldiers, logistics, maintenance, and uniform ammunition. RBS-70NG is also fully compatible with the established automated command and control system of ground air defense fire. The flow of information in an electronic form has created a unified the internal communication and with the environment, which also houses modern methods of streamlining of the organization's logistics processes based on the capabilities of information technologies [28].

State-of-the-art air defense systems replace the obsolete S10 systems and show the direction the CAF is taking in the modernization process. Tatra vehicles with ReVISOR radar technology are included.

\section{Skills Required 2030}

The Czech Armed Forces should do defense capabilities against external assaults, ensuring the sovereignty and territorial integrity of the Czech Republic and meeting international commitments, including participation in 
securing collective defense. At the same time, it should keep up protection capabilities against a weapon of mass destruction and passive surveillance systems as part of joint surveillance reporting in a survey and a target allocation.

The CAF strategic level command and control will be ensured by the General Staff, who will also be responsible for the planning of construction, comprehensive and capacity development, preparation, and CAF unit's use. It will have the ability to create concepts, doctrines, and regulations and will take part in the performance of state administration within its competence.

The operational level of command and control will be ensured by the Operations Command (OperCom). OperCom will command the ground, air, cyber, and OperCom subordinate forces. OperCom will have the ability to plan and conduct joint operations and command all deployed forces and assets in operations both within and outside the Czech Republic.

The tactical level of command and control will be ensured by the Ground Forces Command, the Air Force Command, the Cyber Force and Information Operations Command, and the Territorial Command.

\subsection{Czech Air Force}

The air force will consist of tactical, helicopter and transport aviation, ground air defense troops, command and control forces and means, air traffic control service, air radio navigation service, and intelligence means. The main task of the Air Force (AF) will be to make sure the inviolability of the airspace of the Czech Republic. AF will be able and ready to protect designated objects important for the defense of the state and support the activities of other types of forces of the ACR and allied forces. They will be able to detect, track, find, and counteract a range of airborne and ground targets under all conditions, and advanced electromagnetic interference.

The need to build a missile defense capability will be decided in cooperation with NATO. The bilateral classified voice and data communication capability using standardized NATO protocols are implemented in all units, and combat means operating in the airspace of the Czech Republic. An electronic identification unified allied system implemented in air and ground objects will be introduced.

With new weapon systems and used ammunition AF ensure effective action against targets with the required least risk of endangering own forces and incurring secondary losses. Within the Czech Republic's commitments, forces and resources earmarked as the AF module will be maintained. Training of AF personnel will be provided by contractors.

Tactical Air Force will be the main force to ensure the protection of airspace in the Czech Republic. This capability will be maintained within the NATO Integrated Air Defense and Missile Defense System (NATINAMDS), and the National Air Defense Boost System of the Czech Republic.

AF will achieve a high level of interoperability and the ability to provide support for Ground Forces operations in all weather conditions, day and night, including the ability to counteract air and ground targets. Supersonic Air Force will use its capabilities in space and time to protect the airspace of the Czech Republic within NATINAMDS and to destroy ground targets located beyond the reach of subsonic aviation. It will have the ability of regular deployment to fulfill the tasks of Air Policing in NATO airspace outside the Czech Republic and the ability to deploy a swarm of aircraft to the Task Force. In 2030, the supersonic air force will have a sufficient number of supersonic tactical aircraft. The subsonic air force will complement the capabilities of the supersonic air force.

Helicopter Air Force, designed to carry out combat support tasks, will perform direct air support tasks in favor of the TF Ground and Special Forces, as well as tasks for the transport of persons and material and the removal of the wounded. Will be able to destroy armored targets with precisely guided ammunition. It will continue to have the capabilities to provide air rescue services, air search, and rescue services, and NaPoSy air defense services.

The Air Force will carry people, material and carry out tactical transport of combat units and airborne troops at short and medium distances. It shall ensure the fulfillment of the tasks of transport of constitutional officials of the Czech Republic. Strategic transportation of people, material of larger volumes, technology, and refueling in flight that exceed their own capabilities will be ensured by participation in international programs.

Ground-based air defense will consist of short-range anti-aircraft missile systems with the possibility of using extended-range missiles and very short-range systems, complemented by systems against unmanned aerial vehicles, missile, artillery and mortar fire. All systems will be interfacing with other entities of national and alliance command and control systems and will have the ability to detect, track, find, and cut a range of air targets.

Means providing ground forces air defense gain the ability to act on air attack equipment while moving. Ground forces task force will be ensured ensembles VSHORAD (Very Short Range Air Defense).

The air traffic control service and aeronautical radio navigation service will continue to have the capability to give air and operational services to military and civil air traffic in specified parts of the airspace of the Czech Republic, about the principles of the Single European Sky.

The civil-military integration development of the air traffic services provision will continue to ensure the continuous provision of air navigation services in peace, crisis, or war. 
Aircraft deployments shall have the capability to direct air support.

Command, control, and reconnaissance will use the unified Alliance Command and Control System (ACCS) with which the SSCs will be interoperable. The Czech Republic airspace survey will be able to give continuous radar coverage in a 3D format to detect, find, and track targets at altitudes above $3 \mathrm{~km}$, and in the interest areas from low altitudes.

Radiotechnical troops will have the ability to integrate aerodrome radar information, passive surveillance systems, and NATO reconnaissance capabilities into the air picture. The AF and Ground Forces interconnection systems will enable the creation and distribution of a common operational picture of the situation. AF will continue to take part in NAEW \& C / AFSC.

\subsection{Supersonic Air Force Aircraft}

The Czech Republic's airspace protection, the fulfillment of the Czech Republic's alliance commitments, and the support of the land-based TF will be ensured by a sufficient number of modernized or newly acquired supersonic tactical aircraft.

The subsonic air force will be modernized and used depending on the overall capabilities of the supersonic air force. A new helicopter platform with the ability to use precisely-guided munitions against armored targets will be fully deployed. Mi- 8 will be replaced by a new transport helicopter. The ability to transport passengers over long distances will be enhanced by the purchase of a small airliner. Furthermore, NATO standard navigation means will be introduced for the Chotusice and Sedlec - Vícenice airbases.

To secure the air defense ground forces, non-military and military objects important for the defense of the state will increase the number of ensembles SHORAD with the ability to act on the means of air attack even while moving. The counteract unmanned tactical, missile, artillery, and mortar fire ability by acquiring C-UAS and C-RAM systems, will be achieved.

\subsubsection{Human Resources}

The necessary condition will be age and rank structure of military personnel stabilization, creation of a robust system of recruitment and length of service modality to respond adequately to the situation on the labor market, economic development, and the will of Czech citizens to serve in the CAF.

The number of active soldiers is expected to reach $30,000[27,28]$.

Table 1.

Increase in budgetary numbers to ensure operational needs in the subordination of the ACR [29]

\begin{tabular}{|c|c|c|c|c|c|c|c|c|c|c|c|}
\hline Category/year & $\mathbf{2 0 1 5}$ & $\mathbf{2 0 1 6}$ & $\mathbf{2 0 1 7}$ & $\mathbf{2 0 1 8}$ & $\mathbf{2 0 1 9}$ & $\mathbf{2 0 2 0}$ & $\mathbf{2 0 2 1}$ & $\mathbf{2 0 2 2}$ & $\mathbf{2 0 2 3}$ & $\mathbf{2 0 2 4}$ & $\mathbf{2 0 2 5}$ \\
\hline Soldier & 18 & 19 & 20 & 21 & 22258 & 23 & 24 & 24 & 24 & 24 & 24 \\
& 058 & 100 & 200 & 258 & & 258 & 162 & 162 & 162 & 162 & 162 \\
\hline
\end{tabular}

Table 2.

Number of professional soldiers by rank

\begin{tabular}{|c|c|c|c|c|c|c|c|}
\hline Year & Generals & $\begin{array}{l}\text { Senior } \\
\text { officer }\end{array}$ & $\begin{array}{l}\text { Junior } \\
\text { officer }\end{array}$ & Warrant & NCOś & $\begin{array}{l}\text { Rank and } \\
\text { file }\end{array}$ & $\begin{array}{c}\text { Preparatory } \\
\text { Corps }\end{array}$ \\
\hline 2015 & 19 & 2027 & 3418 & 6224 & 7474 & 828 & 1464 \\
\hline 2016 & 25 & 2094 & 3596 & 6654 & 7829 & 1021 & 1485 \\
\hline 2017 & 28 & 2079 & 3739 & 6923 & 8364 & 1214 & 1422 \\
\hline 2018 & 27 & 2111 & 3877 & 7151 & 8800 & 1348 & 1346 \\
\hline 2019 & 29 & 2211 & 3889 & 7646 & 8764 & 1164 & 1592 \\
\hline
\end{tabular}

\subsubsection{Source Background}

In line with the requirements of the Defense Investment Pledge and in line with the Defense Strategy of the Czech Republic and the Long-term Defense Outlook 2035, the MoD budget is expected to be gradually increased with a target of $1.4 \%$ of GDP by 2021 [30] in 2024 the share of the defense budget in GDP will reach $2.0 \%$. 


\subsubsection{Financial Demands}

The basic prerequisite for effective defense of the state is the continuous creation of a sufficient source framework for the Ministry of Defense. Ensuring sufficient funding is necessary for the decisive modernization projects implementation, creating the required supplies of military material, covering the costs of maintaining and replenishing military personnel, ensuring sufficient preparation and other measures specified in this concept, creating conditions for adequate security and defense of the Czech Republic; fulfillment of commitments to our allies in NATO and the EU.

The modeling of funds in years is based on a political commitment, which is then projected into the interdepartmental planning documents, namely the achievement of a $\%$ of GDP defense spending ratio by 2024 and their continuing stability at this level. This value corresponds to the NATO commitment to increase defense spending, approved at the NATO summit in Wales in 2014, to which the Czech Republic and other alliance allies subscribed.

The Government will keep the minimum investment in major technologies at 20\%, including related research within NATO's overall budget. The share of defense expenditure in GDP is expressed in Table 2, which should, by its linear increase, make sure the achievement of the declared political commitment in 2024 and its later stability by 2030.

These shares were also the basic planning basis for setting the overall financial framework for CAF development concept. This planning framework is without prejudice to the budgetary process independence by Act No. 218/2000 Coll., Budgetary Rules, as amended.

Table 3.

Budget development of the Ministry of Defense of the Czech Republic[31]

\begin{tabular}{|c|c|c|c|c|c|c|c|}
\hline & $\mathbf{2 0 1 9}$ & $\mathbf{2 0 2 0}$ & $\mathbf{2 0 2 1}$ & $\mathbf{2 0 2 2}$ & $\mathbf{2 0 2 3}$ & $\mathbf{2 0 2 4}$ & $\mathbf{2 0 2 5}$ \\
\hline GDP & 5627 & 5880 & 6128 & 6382 & 6510 & 6640 & 6773 \\
\hline Total limit & 66,73 & 75,53 & 85,79 & 102,11 & 117,17 & 132,80 & 135,45 \\
\hline Share of GDP (\%) & 1,19 & 1,28 & 1,40 & 1,60 & 1,80 & 2,00 & 2,00 \\
\hline
\end{tabular}

\subsubsection{Material Resources [32]}

The third basic source for the implementation of the concept is technology, materiál, and modern technology. Appropriate choice of new technologies that are acquired within the construction and modernization of the Army of the Czech Republic is essential. It is necessary to make sure the management of the preparation and implementation of armaments, central procurement of assets and services by public procurement is transparent and effective so that the acquisitions meet the real needs of the Czech Armed Forces and achieve maximum efficiency while ensuring security of supply.

Development and modernization projects implemented as part of the concept implementation will be financially covered from existing programs.

The modernization projects funding will be provided by the new development programs to achieve the Milestones 2025, 2030, and to secure the financing of newly created military units and facilities

The CAF activities in foreign operations and international exercises, and national exercises to keep up interoperability with the Allies and the development of the CAF combat capabilities will be secured by funds to the necessary extent.

The CAF deployment and resources in foreign operations under the Enhanced Response Force or the European Battle Group will be ensured outside the budget of the Ministry of Defense [33].

\section{Unmanned Aerial Reconnaissance of Ground Targets AGS (Alliance Ground Surveillance)}

The governments decided, in 2007, to set up a fleet of eight unmanned reconnaissance aircraft Global Hawk. This number has gradually decreased to the current five machines due to the limited resource framework.

Fifteen participating countries signed the AGS Memorandum of Understanding (MOU) in September 2009 and created the NATO AGS Management Organization (NAGSMO).

Thirteen member countries, including the Czech Republic, were involved in funding the AGS project of $€ 1.2$ billion.

The Czech Republic's contribution is based on a pre-defined NATO security investment key, accounting for about 1.7 percent of the total cost of system acquisition.

Given the limited availability of financial resources in the Czech Republic, the condition for remaining in the 
program was that the Czech defense industry would also participate in the project, which would receive a certain share in building the system in the form of offsets. This is to reach up to 70 percent of the amount the country has spent on building the system. Specifically, it concerns software development in which the Czech company ICZ is involved. The Pardubice company Retia from the CSG holding supplied special containers to the project, which serve as a mobile ground station.

The lifetime of the project is planned for twenty years from the introduction of the AGS system into operation. All NATO member nations, except France and the United Kingdom, have been involved in funding the system operation with the estimated cost of two billion euros (annually 79,3 million euros). The AGS ground reconnaissance alliance project is designed to bring the power of information superiority over any adversary that may not be military. It allows permanent monitoring of large areas from high altitudes, under any weather, thanks to its advanced sensors that give a ground situation comprehensive picture for planning procedures.

Five Global Hawk unmanned aircraft will be delivered to the Main Operational Base (MOB) in Sigonella. The UAVs dislocation will be preceded by verification of the ground infrastructure functionality and transfer to ground control stations. The Global Hawk RQ-4B Block 40 HALE (Multi-Platform Radar Technology Insertion Program) is capable of detecting moving ground targets and Synthetic Aperture Radar (SAR).

The Italian Aviation Authority Directorate of Air Armaments and Airworthiness (DAAA) is certifying for EU operations. The handover and overflight process commencement was planned for the first half of 2019, depending on the certification completion. Failure to complete this certification may jeopardize the date of initial operational capability planned for the turn of 2019/2020. Full operational capability cannot be expected until 2021.

The total contract reaches the level of 40 billion crowns and opens the space for further participation of the CAF and the Czech defense industry. AGS consists of three basic segments. These are the air, ground, and support segments. The air segment consists of five R1-4B Global Hawk Block 40 drones that will be equipped with MP-RTIP radar and added sensors. Furthermore, the air segment includes a transmission system consisting of a broadband LOS (Line Of Sight) datalink and a Ku-Band SATCOM datalink.

The ground segment will serve as an interface between the AGS and a range of command and control systems, both in the field and in Alliance permanent headquarters, including reach-back workplaces2.

It also includes ground control stations. Specifically, there will be two TGGS stations to support operational level components. The equipment will be located in air-conditioned tents and can be operated by up to eleven people. In addition, six MGGS stations will be available to support units at a tactical level. They will consist of lorries with box bodies operated by two-men crew each.

The ground segment will include a number of ground-based equipment in various configurations to get data-link connectivity, data processing, and evaluation. Another important fact is that it will be able to use data for interoperability with Command and Control, Intelligence, Surveillance, and Reconnaissance systems.

The third segment of AGS is logistics support. Individual workplaces and facilities at MOB Sigonella will be earmarked for the support segment.

Slot radar with active electronic beam deflection will be able to map the Earth's surface with extreme accuracy under all weather conditions. Thus, it will enable localization and identification of virtually all ground and surface stationary and moving targets. The GMTI (Ground Moving Target Indicator) location technology, using the Doppler principle, can automatically distinguish moving targets from the background.

They will also be able to check their trajectory and predict further movement based on the characteristics of the target and the surrounding terrain. The technology should be able to compare minor changes in the terrain with stored digital map data and thereby detect new surface treatments, military-important buildings, or deceptive targets. There will be up to several tens of thousands of moving objects in the radar field of view. Data transmission should take place via standard means of communication or satellite connection almost in real-time.

Basically, the ground station operators will be able to receive the necessary data, evaluate it, transmit it to the designated unit, and send it back to the main operating base via satellite. From there, the data or the resulting product will be sent to users at the strategic level of command and national elements. It will also be possible to transmit Global Hawk data via satellite directly to the main operating base in Sigonella. The control center will ensure data distribution to end-users. In this way, it will be possible to give information to decision-makers from the tactical to the strategic level. The armies of all NATO countries will be able to link the information obtained through the AGS with the national command and control systems.

The Global Hawk can hold up to 30 hours in the air. It flies at an altitude of up to twenty kilometers and can act independently on two orbits in parallel. According to the original plan, the AGS was supposed to fly three thousand

\footnotetext{
${ }^{2}$ The ground segment will serve as an interface between the AGS and a range of command and control systems, both in the field and in Alliance permanent headquarters, including reach-back workplaces.

https://www.terrelibere.org/3760-alliance-ground-surveillance-important-nato-visit-to-sigonella/
} 
flight hours per year with five UAVs. It was supposed to be on two orbits twenty-four hours a day, seven days a week for thirty days, with the plane being replaced directly in orbit. With five machines, it is possible to give two 24-hour take-offs a week ten months a year.

In the event of an emergency, it is possible to have two machines continuously in the air twice a year for one month. Together with the surveillance systems of France and Great Britain, which will complement the AGS as needed, the system will be highly flexible and can be tailored precisely to the requirements of NATO missions.

\section{Conclusions}

The Czech Armed Forces will, in the near future, solve the problem of acquisitions or the lease of supersonic aircraft extension. Finding the answer to the question of what supersonic aircraft we will protect our airspace is a political matter.

Is it possible, to extend the rental of Saab JAS 39 Gripen fighters, or to choose more powerful F-16 or F-35 JSF?

JAS-39 Gripen lease period will end in 2027 and cost of 40 billion. Given the expected fighters length production (about three years), pilots training, ground staff preparation (about two years), and complex acquisition management, it is necessary to calculate within a 7 year period. Purchasing such advanced and fundamentally military techniques, such as supersonic fighters, is also reflected in the strengthening of US diplomatic relations with the Allies.

According to one of the most influential managers of the Czech aviation industry, the choice of fighters determines the country's political orientation for many years to come. The estimated price of the F 35 is for partner countries and countries that have bought it through foreign military sales „, came just under $\$ 80$ million. However, the Czech Air Force is currently struggling with a different problem - an extreme fighter pilot overload.

Currently, 21 pilots fly with 14 Gripen fighters and carry out the country air protection tasks, emergency, and foreign missions. Advanced training is another mandatory activity that requires time. In the near future, the Czech Armed Forces will solve the problem of acquisitions or extension of the lease of supersonic aircraft. Finding the answer to the question of what supersonic aircraft we will protect our airspace is a political matter. Is it possible to extend the rental of JAS-39 Gripen fighters, or to choose more powerful machines F-16 or F-35 JSF? JAS-39 Gripen lease period tends in 2027 at the cost of 40 billion.

Given the expected length of fighter's production, about three years, training of pilots and ground personnel, about two years, and complex acquisition management, it is necessary to calculate with a 7-year period. Purchasing such advanced and fundamentally military techniques, such as supersonic fighters, is also reflected in the strengthening of US diplomatic relations with the Allies. The choice of fighters determines the country's political orientation for many years to come.

The estimated price of F 35 is below \$ 80 million for partner countries. However, the Czech Air Force is currently struggling with a different problem - an extreme overload of fighter pilots. With 14 Gripen fighters, 21 pilots fly the air protection tasks of the country, 24/7 emergency, training, but also foreign missions at the cost of much overtime and extreme strain.

The end of the provisional are two squadrons of fighters, 24 machines, which, with adequate staffing to cut the overload of pilots and ground personnel.

\section{Acknowledgements}

This work was conducted within the framework of the Czech Armed Forces acquisition process and the life cycle engineering and life cycle cost. "A theoretical investigations of current modernization process and military spending the projected evolution of the defense budget in the context of air traffic security in all its areas.

The authors are thankful for the close cooperation with Support division and Logistics Agency.

\section{References}

1. Summit NATO v Londýně 2019, http://www.natoaktual.cz/special-summit-nato-v-londyne-2019-70-let-natofja-/na_projekty.aspx?c=A191125_102327_na_projekty_m02

2. Sandberg, A., Strömberg, U. (1999), "Gripen: with focus on availability performance and life support cost over the product life cycle”, Journal of Quality in Maintenance Engineering, Vol. 5 No. 4, pp. 325-334. https://doi. org/10.1108/13552519910298082

3. Hato, E. M. Y. M. H., et al. "Incorporating an information acquisition process into a route choice model with multiple information sources." Transportation Research Part C: Emerging Technologies 7.2-3 (1999): 109-129.

4. Buede, Dennis M., Terry A. Bresnick. "Applications of decision analysis to the military systems acquisition process." Interfaces 22.6 (1992): 110-125.

5. Alting, L. "Life cycle engineering and design.” Cirp Annals 44.2 (1995): 569-580. 
6. Ribeiro, I. et al. "Life cycle engineering methodology applied to material selection, a fender case study." Journal of Cleaner Production 16.17 (2008): 1887-1899.

7. Litman, T. “Transportation cost and benefit analysis.” Victoria Transport Policy Institute 31 (2009).

8. Thomas, Brinda A., Inês L. Azevedo. "Estimating direct and indirect rebound effects for US households with input-output analysis. Part 2: Simulation.” Ecological Economics 86 (2013): 188-198.

9. Phang, Sock-Yong. "Strategic development of airport and rail infrastructure: the case of Singapore." Transport Policy 10.1 (2003): 27-33.

10. Javid, M., Prianka N. Seneviratne. "Investment risk analysis in airport parking facility development." Journal of Construction Engineering and Management 126.4 (2000): 298-305.

11. Dhillon, Balbir S. Life cycle costing for engineers. Crc Press, 2009.

12. Ishii, K., C. F. Eubanks, M. Marks. "Evaluation methodology for post-manufacturing issues in life-cycle design." Concurrent Engineering 1.1 (1993): 61-68.

13. Kozuba J., Pila J., Safety of complex aircraft ergatic systems, Transport Problems Vol. 14, Issue: 2, Gliwice 2019, pp.101-111, ISSN: 1896-0596

14. Candell, O., Ramin K., Söderholm, P. “eMaintenance-Information logistics for maintenance support.” Robotics and Computer-Integrated Manufacturing 25.6 (2009): 937-944.

15. Levrat, E., Iung, B., Crespo, Marquez A. "E-maintenance: review and conceptual framework."

16. Production Planning \& Control 19.4 (2008): 408-429. Summit NATO v Londýně 2019, http://www.natoaktual.cz/ special-summit-nato-v-londyne-2019-70-let-natofja-/na_projekty.aspx?c=A191125_102327_na_projekty_m02

17. HEIJUNGS, R., HUPPES, G., GUINÉE, Jeroen B. Life cycle assessment and sustainability analysis of products, materials and technologies. Toward a scientific framework for sustainability life cycle analysis. Polymer degradation and stability, 2010, 95.3: 422-428.

18. Johnson, Forrester T.; Tinoco, Edward N.; YU, N. Jong. Thirty years of development and application of CFD at Boeing Commercial Airplanes, Seattle. Computers \& Fluids, 2005, 34.10: 1115-1151.

19. Piątkowski, J., Wieszala R. 2019. Crystallization and structure of AlSi10Mg0.5Mn0.5 alloy with dispersion strengthening with Al-FexAly-SiC phases, Metals vol. 9 iss. 8, art. no. 865 s. 1-8,

20. WU, Haiqiao, et al. Methods to reduce direct maintenance costs for commercial aircraft. Aircraft Engineering and Aerospace Technology, 2004.

21. Barnhart, C., BELOBABA, P., Odoni, Amedeo R. Applications of operations research in the air transport industry. Transportation science, 2003, 37.4: 368-391.

22. vanHeerden,Derk-Jan,Curan,R.,AircraftEnd-of-LifeSolutions,EnvironmentalImpact,ManufacturingandOperations, 15 December 2010, Print ISBN: 9780470754405| Online ISBN: 9780470686652| DOI: 10.1002/9780470686652, https://onlinelibrary.wiley.com/doi/abs/10.1002/9780470686652.eae355

Stark., John. Product lifecycle management. In: Product lifecycle management (Volume 1). Springer, Cham, 2015. p. 1-29.

23. Sandberg, A.,Strömberg, U. (1999), „Gripen: with focus on availability performance and life support cost over the product life cycle“, Journal of Quality in Maintenance Engineering, Vol. 5 No. 4, pp. 325-334. https://doi.org/10.1108/13552519910298082

24. Kozuba J., Pila J., Safety of complex aircraft ergatic systems, Transport Problems Vol. 14, Issue: 2, Gliwice 2019, pp.101-111, ISSN: 1896-0596

25. Obranná strategie České republiky, http://www.mocr.army.cz/images/id_40001_50000/46088/Obrann strategie_2017_-_CZ.pdf

26. Nemocnici ochromil počítačový virus. Pacienty z JIP a ARO odvezou: https://n.nova.cz/clanek/pocitacovy virus-ochromil-nemocnici-v-benesove-pacienti-museji-jinam.html

27. Struktura Armády České republiky a počty vojáků ozbrojených sil České republiky

28. Kozuba J., Kunert O., Strategic management of motivation and salaries at airports, Proceedings of the International Scientific Conference Transport Means 2016, ISSN 1822-296X / ISSN 2351-7034, October 5-7, 2016, Book 1, pp. 216-223

29. Koncepce výstavby Armády České republiky 2025, http://www.mocr.army.cz/images/id_40001_50000/46088/ KVA_R_ve_ejn__verze.pdf,

30. Programové prohlášení vlády České republiky. Dostupné z: https://www.vlada.cz/cz/jednanivlady/programoveprohlaseni/programove-prohlaseni-vlady165960/\#Obranna_politika_a_Armada_Ceske_republiky

31. Koncepce výstavby Armády České republiky 2025, http://www.mocr.army.cz/images/id_40001_50000/46088/ KVA_R_ve_ejn__verze.pdf,

32. http://www.mocr.army.cz/images/id_40001_50000/46088/koncepce_2030.pdf

33. Usnesení vlády ČR ze dne 22. 10. 2007 č. 1194 bod I/3. 